\title{
Pengembangan media pembelajaran AIKO berbasis aplikasi android dari PowerPoint materi pertumbuhan dan pembangunan ekonomi kelas XI
}

\author{
Nazilatul Muharrami Nasifa, Ro'ufah Inayati* \\ Universitas Negeri Malang, Jl. Semarang No. 5 Malang, Jawa Timur, Indonesia \\ *Penulis korespondensi, Surel: roufah.inayati.fe@um.ac.id
}

Paper received: 6-8-2021; revised: 20-8-2021; accepted: 28-8-2021

\begin{abstract}
Being in the industrial era 4.0, teachers as educators are required to understand technology more than their students. Teachers need to understand students' needs for technological developments so that classroom learning runs well. The development of learning media is one of the alternative solutions that can be used by teachers to meet the needs of students for technological developments. The purpose of research and development is to produce learning media products based on android applications from Microsoft PowerPoint on material for economic growth and development for class XI. This research and development uses the ADDIE model. The results of the research and development were obtained from the results of the feasibility test through filling out validation questionnaires with validators of material experts (lecturers), media experts (lecturers), learning practitioners (economics teachers), and test results with users (students) through small group trials and large group trial. The average result of the validation and testing as a whole obtained a score of $92.177 \%$ so that this research and development product is very valid and very feasible to be used as a learning medium.
\end{abstract}

Keywords: learning media; android; microsoft powerpoint; economic

\begin{abstract}
Abstrak
Berada pada era industri 4.0 guru sebagai pendidik diharuskan untuk memahami teknologi lebih dari siswanya. Guru perlu memahami kebutuhan siswa atas perkembangan teknologi agar pembelajaran di kelas berjalan dengan baik. Pengembangan media pembelajaran menjadi salah satu solusi alternatif yang bisa digunakan oleh guru untuk memenuhi kebutuhan siswa atas perkembangan teknologi. Tujuan dari penelitian dan pengembangan adalah untuk menghasilkan produk media pembelajaran berbasis aplikasi android dari Microsoft PowerPoint pada materi pertumbuhan dan pembangunan ekonomi kelas XI. Penelitian dan pengembangan ini menggunakan model ADDIE. Hasil dari penelitian dan pengembangan diperoleh dari hasil uji kelayakan melalui pengisian kuisioner validasi bersama validator ahli materi (dosen), ahli media (dosen), praktisi pembelajaran (guru ekonomi), dan hasil uji coba bersama pengguna (siswa) melalui uji coba kelompok kecil dan uji coba kelompok besar. Rata-rata asil validasi dan uji coba secara keseluruhan memperoleh skor sebesar $92,177 \%$ sehingga produk penelitian dan pengembangan ini sangat valid dan sangat layak untuk digunakan sebagai media pembelajaran.
\end{abstract}

Kata kunci: media pembelajaran; android; microsoft powerpoint; ekonomi

\section{Pendahuluan}

Era revolusi industri 4.0 menekankan pada digital economy, artificial intelligence, big data, dan robotic. Hal ini menuntut dunia pendidikan harus mengkonstruksi kreativitas, pemikiran kritis, penguasaan teknologi, dan kemampuan literasi digital (Subagyo, 2018). Berada pada era industri 4.0 guru sebagai pendidik diharuskan untuk memahami teknologi lebih dari siswanya. Guru perlu memahami kebutuhan yang diperlukan oleh siswa atas perkembangan teknologi agar pembelajaran di kelas berjalan dengan baik. Munculnya 
kebutuhan siswa dalam proses pembelajaran disebabkan karena adanya tujuan di dalam diri siswa yang harus dipenuhi. Ketika kebutuhan tersebut dapat terpenuhi dengan baik maka proses pembelajaran akan berjalan dengan lancar.

Kemajuan teknologi membuat perubahan besar dan menjadi topik yang sangat populer diperbincangkan di seluruh lapisan masyarakat. Hal ini juga berakibat pada munculnya istilah seperti "digital native", "google generation", atau "millenials" di kalangan generasi muda. Generasi muda, khusunya siswa masa kini cenderung memiliki kebutuhan di dalam proses pembelajaran yang berbeda dengan generasi-generasi sebelumnya. Supriyoko (2019) berpendapat di dalam Dialog Terbatas Fraksi PKS DIY Komisi A DIY, dalam pembelajaran saat ini yang terjadi di sekolah adalah adanya pertemuan antara siswa sebagai digital natives dan guru yang masuk pada kategori digital immigrants. Prensky (2001) mendefinisikan generasi digital natives adalah generasi anak muda yang lahir di era digital, dimana teknologi telah menjadi bagian dari lingkungannya, sehingga mudah bagi mereka beradaptasi dengan teknologi baru. Sedangkan, generasi digital immigrants adalah generasi yang lahir sebelum era digital yang kemudian mencoba mengadopsi aspek-aspek teknologi baru dalam kehidupan sehari-hari meskipun sebagian besar tindakan mereka masih dipengaruhi oleh aspek-aspek teknologi lama. Dalam kondisi tersebut, sering terjadi perbedaan cara pandang antara siswa dan guru. Guru sebagai pembuat program di sekolah yang merupakan digital immigrants seringkali menggunakan program lawas tetapi merasa bahwa program yang dibuat sudah bagus untuk diterapkan pada siswa. Sedangkan, siswa yang merupakan digital natives merasa program tersebut tidak perlu. Sehingga kebutuhan siswa sebagai digital natives belum terpenuhi. Oleh karena itu, guru mempunyai peran untuk menganalisis perihal apa saja yang di butuhkan siswa selama proses pembelajaran. Berdasarkan hasil kuisioner yang dibuat pada bulan November 2019, dan wawancara dengan guru pengampu mata pelajaran ekonomi peneliti menemukan temuan di kelas XI IPS 3 SMA Negeri 4 Malang bahwa guru dalam menyampaikan materi sudah menggunakan media Microsoft PowerPoint atau yang disingkat PowerPoint. Meskipun penggunaannya masih dengan tampilan yang belum menarik, dimana PowerPoint yang ditampilkan masih full text dan belum menampilkan gambar yang interaktif. Guru juga tidak pernah menggunakan media lain selain PowerPoint.

Hambatan lain yang ditemukan oleh peneliti adalah kurangnya antusias siswa terkait pelajaran yang disampaikan oleh guru. Sikap siswa cenderung tidak memperhatikan materi dan lebih memilih melakukan kegiatan lain seperti bermain bolpoin, mengantuk, bercakapcakap dengan siswa lain, dan izin ke kamar mandi yang ternyata pergi ke kantin. Untuk penggunaan smartphone, pihak sekolah memperbolehkan siswa membawa smartphone ke sekolah dengan tujuan untuk mencari tambahan referensi materi ketika sumber belajar yang dimiliki tidak lengkap. Guru juga memiliki kewenangan membatasi penggunaan smartphone hanya jika smartphone tersebut dibutuhkan ketika proses pembelajaran. Sebagai contoh, guru menggunakan smartphone untuk mengirim silabus pembelajaran kepada ketua kelas kemudian oleh ketua kelas silabus tersebur di sebarluaskan ke semua siswa dengan di kirim di grup whatsapp kelas. Selebihnya, siswa diminta untuk menonaktifkan smartphone, meskipun masih ada beberapa siswa yang secara sembunyi-sembunyi menggunakan smartphone untuk bermain. Selain itu, sarana dan prasarana di kelas XI IPS 3 SMA Negeri 4 Malang cukup memadai, dilihat dari ketersediaan $L C D$, proyektor, dan tersedianya jaringan internet untuk mendukung kegiatan pembelajaran. Oleh karena beberapa peluang dan hambatan tersebut, proses pembelajaran belum berjalan dengan baik dan materi yang disampaikan oleh guru belum dapat tersalurkan sepenuhnya kepada siswa. 
Penelitian yang dilakukan oleh Cambridge International melalui Global Education Census tahun 2018 menunjukkan bahwa siswa di Indonesia sangat akrab dengan teknologi. Bukan hanya digunakan untuk mengakses media sosial, pemanfaatan teknologi oleh siswa juga digunakan untuk kebutuhan pembelajaran. Hasil penelitian menunjukkan, siswa Indonesia menduduki peringkat tertinggi secara global penggunaan ruang IT/komputer di sekolah dengan persentase sebanyak $40 \%$, penggunaan smartphone di dalam kelas sebanyak $67 \%$, dan penggunaan teknologi untuk mengerjakan pekerjaan rumah (PR) sebanyak $81 \%$. International Data Corporation (IDC) menyatakan penggunaan sistem android menguasai pasar $85,1 \%$ pada tahun 2018. Penggunaan sistem android diperkirakan naik sebesar 1,6\% pada tahun 2019 menjadi $86,7 \%$. Sehingga, tipe smartphone yang sering digunakan oleh masyarakat umum, khususnya siswa dalam proses pembelajaran maupun mengakses media sosial adalah android. Data menunjukkan jumlah keseluruhan siswa kelas XI IPS 3 adalah 27 siswa, dengan komposisi 12 siswa laki-laki dan 15 siswa perempuan dengan tipe smartphone yang mereka miliki ratarata adalah android.

Peneliti kemudian melakukan analisis terkait kebutuhan siswa kelas XI IPS 3 SMA Negeri 4 Malang. Hasil analisis peneliti menunjukkan bahwa siswa membutuhkan inovasi media pembelajaran dengan memanfaatkan penggunaan smartphone tipe android yang dimiliki oleh siswa dan memperbaiki penggunaan media PowerPoint yang digunakan oleh guru agar menjadi lebih menarik. Pemenuhan kebutuhan siswa akan teknologi di dalam proses pembelajaran menuntut guru untuk dapat beradaptasi dengan cepat mengikuti perkembangan teknologi. Banyak ditemukan inovasi baru dalam mewujudkan penguasaan teknologi di bidang pendidikan yang dapat menunjang proses pembelajaran. Salah satu bentuk inovasi tersebut adalah pengembangan variasi media pembelajaran yang dapat digunakan oleh guru sebagai sarana belajar mengajar. Media pembelajaran berbasis android yang dikembangkan ini bernama AIKO (Aku Pintar Ekonomi) yang memuat materi tentang pertumbuhan dan pembangunan ekonomi. Materi ini dipilih karena memiliki indikator pembahasan materi yang banyak dan luas sehingga perlu disampaikan secara menarik agar tidak membosankan.

\section{Metode}

Jenis penelitian ini adalah penelitian riset dan pengembangan atau Research and Development $(R \& D)$ yang berorientasi pada pengembangan produk dan menguji keefektifan dari produk tersebut. Menurut Sugiyono (2012: 407) penelitian dan pengembangan adalah metode penelitian yang digunakan untuk menghasilkan produk tertentu, dan menguji keefektifan produk tersebut. Sukmadinata (2006: 169) mendefinisikan penelitian dan pengembangan merupakan pendekatan penelitian untuk menghasilkan produk baru atau menyempurnakan produk yang telah ada. Dalam penelitian ini peneliti menggunakan model pengembangan ADDIE (analyze, design, development, implementation, dan evaluation). Model ADDIE adalah salah satu model pengembangan yang sistematis. Model ADDIE dikembangkan oleh Dick dan Carry pada tahun 1996 untuk merancang sistem pembelajaran (Mulyatiningsih, 2016).

Pengembangan media ini melewati tahap uji coba produk untuk menentukan kelayakan sebuah produk. Desain uji coba produk mencakup validasi produk, revisi produk, dan uji lapangan yang terdiri dari uji coba kelompok kecil, dan uji coba kelompok besar. Jenis data yang diperoleh dalam penelitian ini adalah data kuantitatif dan data kualitatif. Instrumen pengumpulan data yang digunakan dalam penelitian dan pengembangan ini adalah observasi, wawancara tidak terstruktur, angket, dan dokumentasi. Subjek validasi dan revisi produk 
meliputi validator ahli materi, validator ahli media, dan validator praktisi pembelajaran. Subjek uji coba kelompok kecil terdiri dari 6 siswa dari kelas XI IPS 3 SMA Negeri 4 Malang dan subjek uji coba kelompok besar terdiri dari 21 siswa dari kelas XI IPS 3 SMA Negeri 4 Malang. Angket yang diperoleh dari semua subjek diidentifikasi menggunakan skala Guttman dengan menghitung rata-rata skor jawaban positif dan negatif yang diperoleh, dibagi rata-rata skor keseluruhan dan dikalikan 100\%. Data hasil validasi dan uji coba produk digunakan untuk memastikan pengembangan media pembelajaran ini valid dan layak untuk digunakan. Kemudian, dilakukan analisis terhadap keseluruhan data yang telah diperoleh. Teknik analisis data yang digunakan adalah analisis data kuantitatif dan analisis data kualitatif.

\section{Hasil dan Pembahasan}

Produk yang dihasilkan dalam pengembangan ini berupa aplikasi media pembelajaran yang diberi nama "AIKO" yang merupakan kepanjangan dari "Aku Pintar Ekonomi". Proses pengembangan produk ini dilakukan melalui beberapa tahapan sebagai berikut,

\subsection{Tahap Analisis (Analyze)}

Pada tahap ini, observasi dilakukan oleh peneliti kepada guru dan siswa kelas XI IPS 3 SMA Negeri 4 Malang yang berjumlah 27 orang. Hal ini dibutuhkan untuk mengamati dan melihat kondisi sekolah, permasalahan yang terjadi di kelas, dan kebutuhan siswa. Dalam observasi yang dilakukan oleh peneliti ditemukan bahwa, guru dalam mengajar sudah menggunakan media berupa PowerPoint untuk menyampaikan materi. Akan tetapi, media yang ditampilkan masih berupa tulisan dan background yang kurang menarik. Sedangkan apabila dilihat dari kebutuhan siswa, yang memperhatikan materi rata-rata adalah siswa yang duduk dibagian depan sedangkan siswa di bagian belakang cenderung tidak memperhatikan materi. Selain itu, siswa juga banyak yang memainkan smartphone ketika pelajaran sedang berlangsung untuk mengatasi kebosanan. Selama masa pandemi, pembelajaran daring menjadi alternatif utama yang wajib dilaksanakan agar pembelajaran dapat terus berlangsung. SMA Negeri 4 Malang juga melaksanakan pembelajaran secara daring. Berdasarkan kondisi tersebut, peneliti mengembangkan media pembelajaran android dengan memanfaatkan perkembangan teknologi, kepemilikan siswa atas smartphone android, serta kondisi pembelajaran daring dimana siswa dan guru tidak diperbolehkan untuk bertatap muka selama pandemi untuk kelas XI IPS 3 SMA Negeri 4 Malang.

\subsection{Tahap Perancangan (Design)}

Pada tahap ini, peneliti menentukan media yang sesuai dengan karakteristik peserta didik, tuntutan kompetensi, dan strategi pembelajaran yang diterapkan. Media yang dibuat adalah media yang memanfaatkan aplikasi PowerPoint dan kepemilikan smartphone android siswa. Materi yang digunakan adalah materi pada mata pelajaran ekonomi yaitu KD 3.2 menganalisis konsep pertumbuhan ekonomi dan pembangunan ekonomi serta permasalahan dan cara mengatasinya dan KD 4.2 menyajikan hasil temuan permasalahan pertumbuhan ekonomi dan pembangunan ekonomi serta cara mengatasinya, yang dikemas ke dalam 8 pokok materi. Selanjutnya, peneliti menyusun konten media pembelajaran yang terbagi menjadi tiga bagian. Masing-masing bagian mengandung isi berupa, 1) halaman awal yang terdiri dari cover pembuka, dan menu utama; 2) menu utama yang terdiri dari beranda, petunjuk penggunaan, KI dan KD, materi, video pendukung materi, dan evaluasi berupa kuis; 3) halaman penutup yang terdiri dari profil pengembang. Desain awal media pembelajaran ini dituangkan dalam 
storyboard menggunakan Microsoft Word. Contoh desain menu utama gambar 1 dan desain menu materi gambar 2

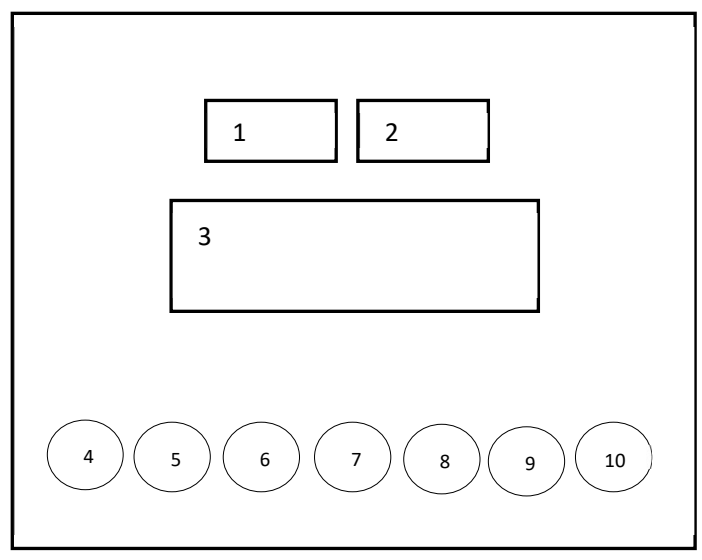

Gambar 1. Storyboard Menu Utama (2021)

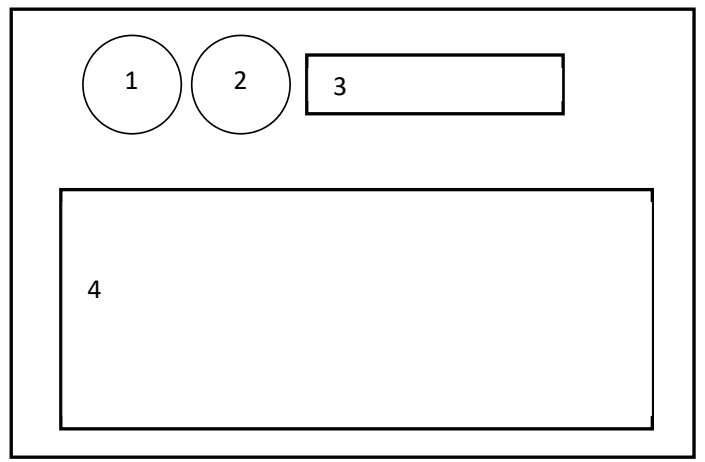

Gambar 2. Storyboard Menu Materi (2021)

\subsection{Tahap Pengembangan (Development)}

Tahap pengembangan adalah tahap dimana peneliti mulai merancang aplikasi meliputi, menentukan ukuran, membuat desain animasi, menyisipkan gambar, teks, video, audio, materi, profil pengembang, kuis untuk evaluasi, menyimpan produk dalam format $h t m l$, dan mengembangkan produk menjadi aplikasi media berbasis android. Pengembangan media pembelajaran pada penelitian ini menggunakan software Microsoft PowerPoint, iSpring Suite 9 dan Website 2 APK Builder. Microsoft PowerPoint digunakan untuk menggabungkan materi dengan memanfaatkan berbagai fitur dalam PowerPoint seperti animasi, transisi, trigger, shapes, dan hyperlink. iSpring Suite 9 digunakan untuk membuat soal-soal berupa kuis evaluasi dan menyimpan media dalam format $h t m l$, serta Website 2 APK Builder untuk mengubah fomat $\mathrm{html}$ menjadi file apk. Tampilan halaman awal produk yang telah selesai dibuat pada gambar 3 dan tampilan menu utama produk pada gambar 4. 


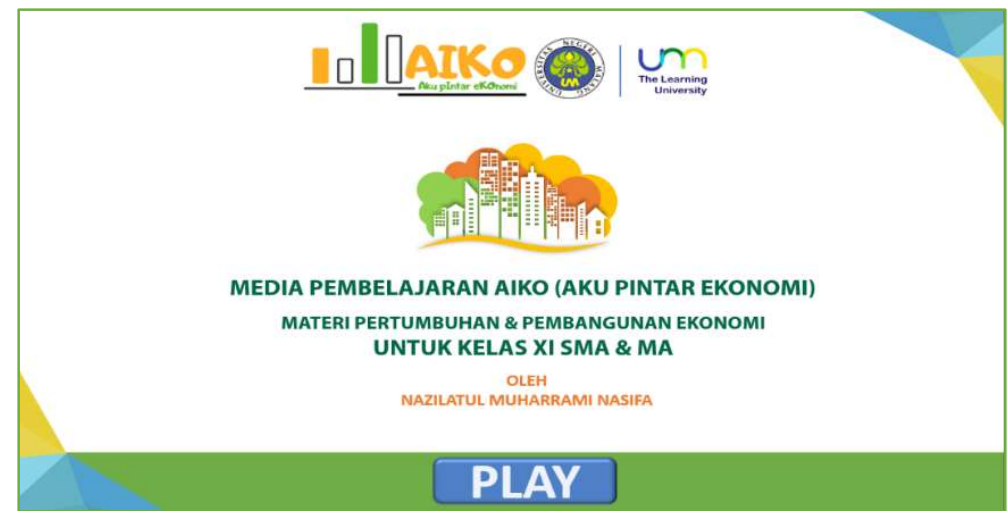

Gambar 3. Tampilan Halaman Awal Produk (2021)

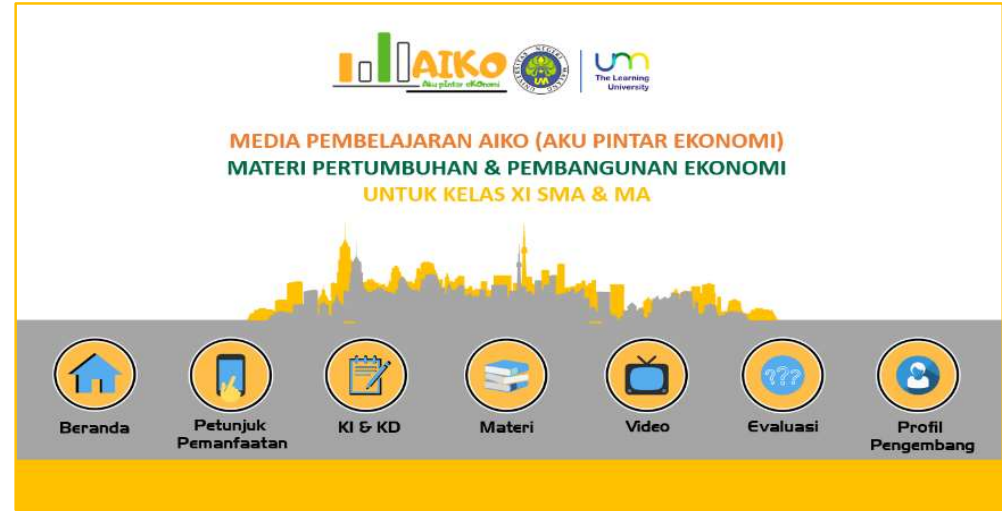

Gambar 4. Tampilan Menu Utama Produk (2021)

Pada menu utama terdapat tujuh pilihan menu, yaitu beranda, petunjuk pemanfaatan, KI dan KD, materi, video, evaluasi, dan profil pengembang. Suara atau audio sudah diatur secara otomatis muncul ketika masuk pada bagian menu utama. Selain terdapat pada bagain menu utama, menu-menu ini dalam bentuk icon atau tombol kecil akan muncul di semua halaman aplikasi. Menu petunjuk pemanfaatan berisi penjelasan tentang bagaimana mengoperasikan media pembelajaran. Menu KI dan KD menjelaskan tentang kompetensi inti (KD), kompetensi dasar (KD) dan tujuan pembelajaran yang harus dicapai. Menu materi menampilkan penjelasan tentang materi yang akan dipelajari dalam aplikasi yang dibuat. Menu materi memuat delapan pokok materi. Gambar 5 menunjukkan tampilan dari menu materi.

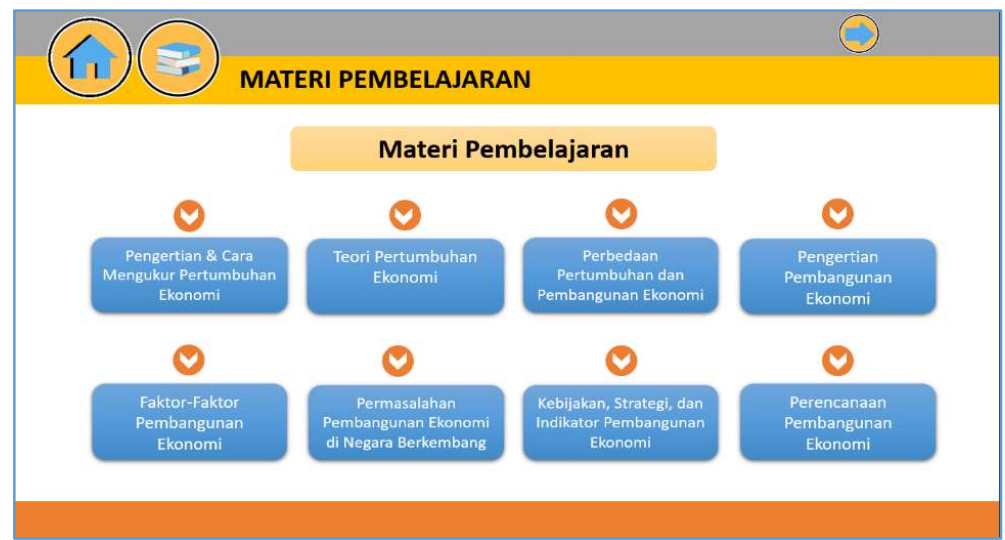

Gambar 5. Tampilan Menu Materi (2021) 
Menu video menampilkan video yang berhubungan dengan materi yang disampaikan. Menu evaluasi menampilkan kuis dan soal sebagai evaluasi bagi pengguna yang sudah mengakses menu materi dan video. Terdapat 10 soal yang harus diselesaikan oleh pengguna dalam waktu 20 menit. Kemudian, halaman penutup produk. Halaman ini menampilkan profil dari pengembang dan dosen pembimbing yang mengembangkan media. Tampilan menu evaluasi pada gambar 6. Tampilan halaman penutup pada gambar 7.

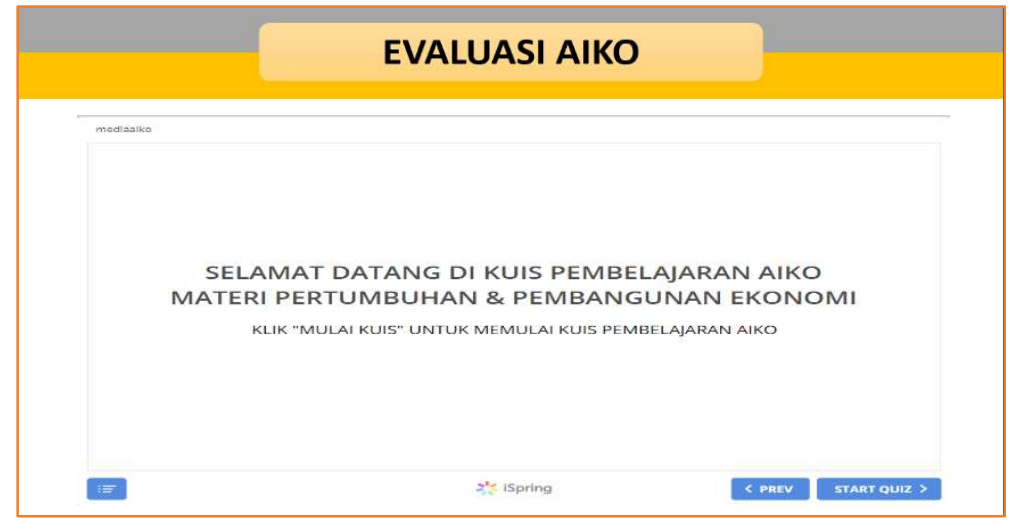

Gambar 6. Tampilan Menu Evaluasi (2021)

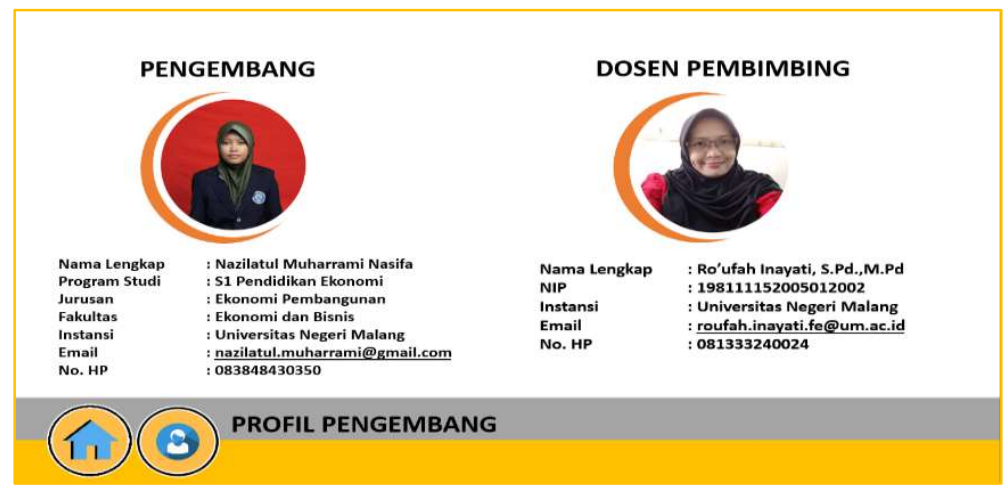

Gambar 7. Halaman Penutup Produk (2021)

Produk yang telah selesai dikembangkan kemudian diuji kelayakannya oleh validator, yang terdiri dari 1) validator ahli materi yaitu dosen ekonomi pembangunan yang ahli dalam materi pertumbuhan dan pembangunan ekonomi, 2) validator ahli media yaitu dosen teknologi pendidikan yang ahli dalam bidang teknologi, 3) validator praktisi pembelajaran yaitu guru mata pelajaran ekonomi di SMA Negeri 4 Malang, dan 4) validator pengguna yaitu siswa kelas XI IPS 3 SMA Negeri 4 Malang. Validasi dilakukan dengan mengisi angket yang disediakan oleh peneliti. Validator memberikan penilaian terhadap produk, kritik dan saran yang diperlukan untuk pengembangan produk, dan kesimpulan apakah produk yang dikembangkan layak untuk digunakan, membutuhkan revisi, atau tidak layak digunakan. 
Tabel 1. Hasil Validasi Ahli Materi

\begin{tabular}{lccc}
\hline No. Aspek Penilaian & \multicolumn{2}{c}{ Skor } & \multirow{2}{*}{ Persentase (\%) } \\
\cline { 2 - 3 } & $\mathrm{X}$ & $\mathrm{X} 1$ & \\
\hline Rerata Relevansi Materi & 5 & 5 & 100 \\
Rerata Keakuratan Materi & 3 & 3 & 100 \\
Rerata Kelengkapan Sajian & 1 & 1 & 100 \\
Rerata Bahasa & 4 & 4 & 100 \\
Rerata Hasil Validasi & 13 & 13 & 100 \\
\hline
\end{tabular}

Sumber: Data Primer Peneliti (2021)

Tabel 2. Hasil Validasi Ahli Media

\begin{tabular}{|c|c|c|c|}
\hline \multirow{2}{*}{ No. Aspek Penilaian } & \multicolumn{2}{|c|}{ Skor } & \multirow[t]{2}{*}{ Persentase (\%) } \\
\hline & $\mathrm{X}$ & $\mathrm{X} 1$ & \\
\hline Rerata Rekayasa Perangkat Lunak & 5 & 5 & 100 \\
\hline Rerata Komunikasi Visual & 7 & 8 & 87,5 \\
\hline Rerata Hasil Validasi & 12 & 13 & 92,307 \\
\hline
\end{tabular}

Sumber: Data Primer Peneliti (2021)

Tabel 3. Hasil Validasi Praktisi Pembelajaran

\begin{tabular}{lccc}
\hline No. Aspek Penilaian & \multicolumn{2}{c}{ Skor } & Persentase (\%) \\
\cline { 2 - 4 } & $\mathrm{X}$ & $\mathrm{X} 1$ & \\
\hline Rerata Aplikasi Pembelajaran & 3 & 3 & 100 \\
Rerata Desain Pembelajaran & 2 & 2 & 100 \\
Rerata Komunikasi Visual & 5 & 5 & 100 \\
Rerata Hasil Validasi & 10 & 10 & 100 \\
\hline
\end{tabular}

Sumber: Data Primer Peneliti (2021)

Tabel 4. Hasil Uji Coba Kelompok Kecil

\begin{tabular}{lccc}
\hline No. Aspek Penilaian & \multicolumn{2}{c}{ Skor } & Persentase (\%) \\
\cline { 2 - 4 } & $\mathrm{X}$ & $\mathrm{X} 1$ & \\
\hline Rerata Rekayasa Perangkat Lunak & 24 & 24 & 100 \\
Rerata Komunikasi Visual & 16 & 18 & 88,89 \\
Rerata Penyajian Materi & 18 & 18 & 100 \\
Rerata Lain-lain & 12 & 12 & 100 \\
Rerata Hasil Uji Coba & 70 & 72 & 97,22 \\
\hline
\end{tabular}

Sumber: Data Primer Peneliti (2021)

Tabel 5. Hasil Uji Coba Kelompok Besar

\begin{tabular}{lccc}
\hline No. Aspek Penilaian & \multicolumn{2}{c}{ Skor } & Persentase (\%) \\
\cline { 2 - 4 } & $\mathrm{X}$ & $\mathrm{X} 1$ & \\
\hline Rerata Rekayasa Perangkat Lunak & 80 & 84 & 95,24 \\
Rerata Komunikasi Visual & 54 & 63 & 85,71 \\
Rerata Penyajian Materi & 62 & 63 & 98,41 \\
Rerata Lain-lain & 42 & 42 & 100 \\
Rerata Hasil Uji Coba & 238 & 252 & 94,44 \\
\hline
\end{tabular}

Sumber: Data Primer Peneliti (2021) 


\section{Tabel 6. Kritik dan Saran Validator}

\begin{tabular}{ll}
\hline Validator & Kritik dan Saran \\
\hline Inayati Nuraini Dwiputri, & Kalimat yang digunakan dalam pembuatan beberapa soal \\
S.Si, M.Sc & $\begin{array}{l}\text { Canth ambigu. } \\
\text { merupakan karya orang lain. Dalam teorinya, sebenarnya } \\
\text { secara implisit pertumbuhan ekonomi juga memperhatikan } \\
\text { pertambahan penduduk. Saran saya opsi B pada soal No.4 } \\
\text { diganti. }\end{array}$ \\
& $\begin{array}{l}\text { Secara umum sudah cukup baik. Optimalisasi pada aspek } \\
\text { desain visual (tata warna, dan komposisi). Lengkapi dengan }\end{array}$ \\
& $\begin{array}{l}\text { Petujuk Pemanfaatan. Warna diubah teks putih, warna latar } \\
\text { Eka Pramono Adi, S.IP., }\end{array}$ \\
M.SI & $\begin{array}{l}\text { Media sudah bagus, bisa diterapkan dan layak untuk diuji } \\
\text { cobakan. }\end{array}$ \\
\hline Ngesti Baju Ratwati, S.Pd, & \\
M.Pd & Sumber: Data Primer Peneliti (2021)
\end{tabular}

\subsection{Tahap Implementasi (Implementation)}

Implementasi produk berupa uji coba penggunaan produk terdiri dari dua langkah uji coba antara lain, 1) uji kelompok kecil yang dilakukan kepada 6 siswa yang terpilih, dan 2) uji lapangan yang dilakukan kepada seluruh siswa kelas XI IPS 3 SMA Negeri 4 Malang. Berikut adalah tampilan langkah-langkah penggunaan media pembelajaran berbasis android AIKO.

\subsubsection{Tampilan Mengunduh Aplikasi dari Google Drive}

Untuk mendapatkan aplikasi AIKO, harus dilakukan pengunduhan aplikasi terlebih dahulu melalui google drive. Pengguna dapat mengunduh file aplikasi AIKO dengan mengakses alamat URL: https://bit.ly/MediaAikonew. Berikut tampilan mengunduh aplikasi dari google drive.

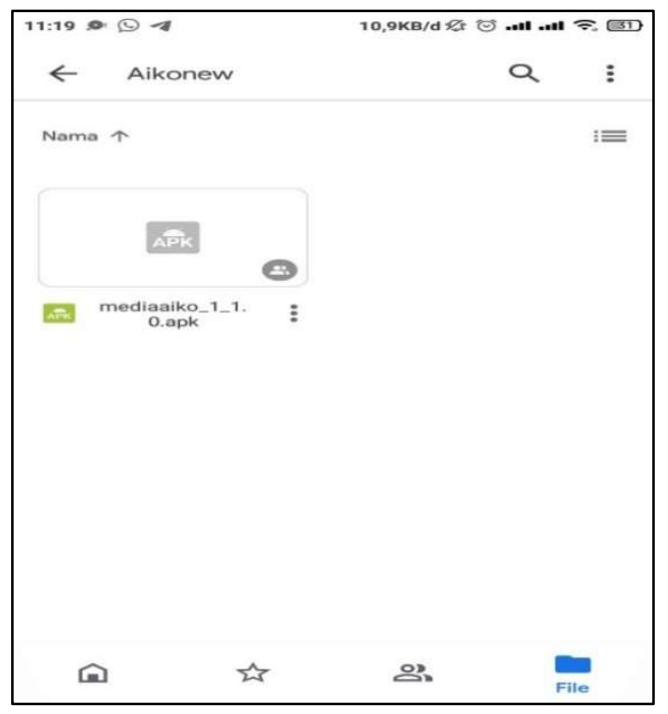

Gambar 8. Tampilan AIKO pada Google Drive 


\subsubsection{Tampilan Install Aplikasi AIKO}

Setelah mendapatkan aplikasi AIKO dari google drive, maka tahap selanjutnya dapat dilakukan pemasangan aplikasi di smartphone.
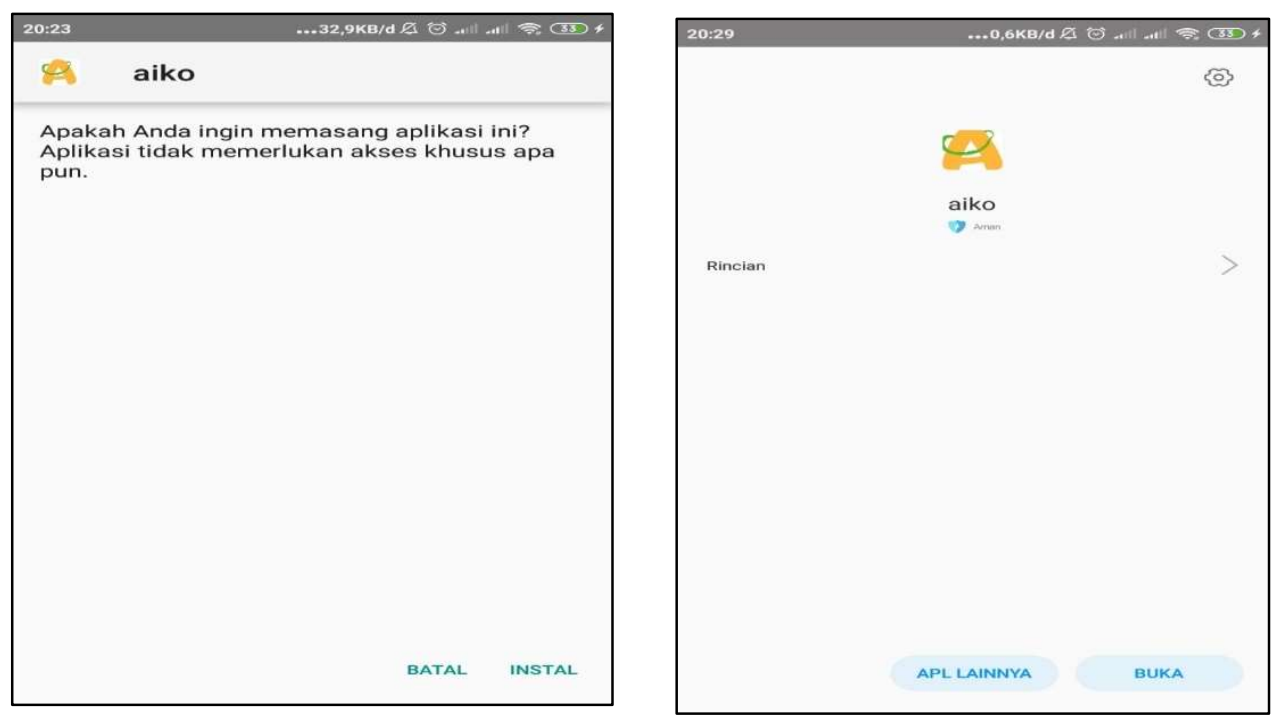

Gambar 9. Tampilan aplikasi AIKO ketika akan di install di smartphone

\subsubsection{Tampilan Keluar dari Aplikasi AIKo}

Setelah selesai menggunakan aplikasi AIKO apabila pengguna ingin keluar dari aplikasi, maka pengguna dapat menekan tombol kembali di smartphone sehingga akan muncul informasi berupa pertanyaan apakah pengguna akan keluar dari aplikasi atau tidak. Pengguna dapat memilih tombol "Oke" apabila ingin keluar, dan memilih tombol "Batal" apabila tidak ingin keluar dari aplikasi.

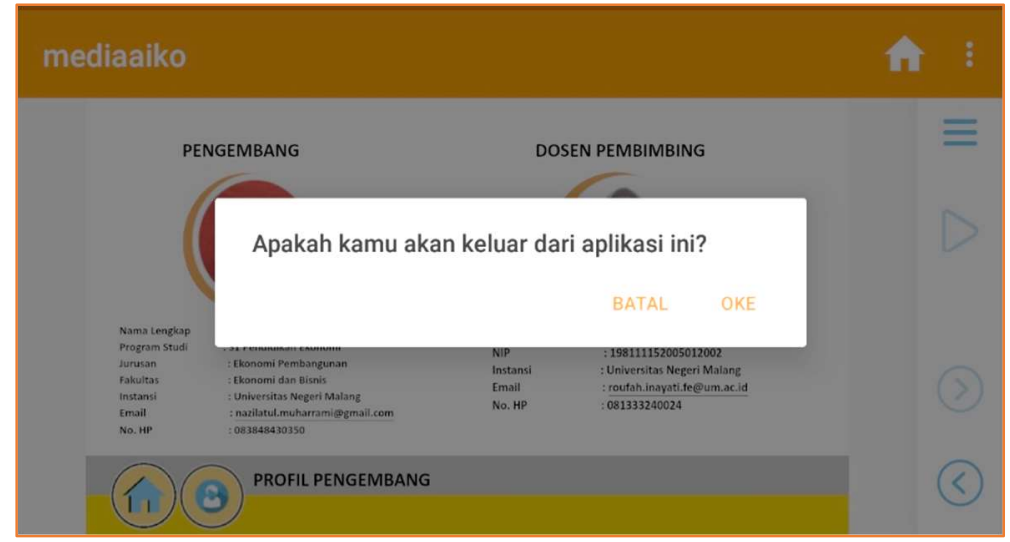

Gambar 10. Tampilan keluar dari aplikasi AIKO

\subsubsection{Tahap Evaluasi (Evaluation)}

Tahap evaluasi bertujuan untuk mengetahui apakah keseluruhan tahap berjalan dengan sesuai atau tidak. Pada tahap ini, peneliti banyak melakukan evaluasi pada proses pembuatan 
produk, yaitu pada tahap pengembangan (development). Evaluasi dalam tahap pengembangan sering dilakukan mengingat masih banyak revisi terhadap produk yang sedang dibuat.

\section{Simpulan}

Media pembelajaran AIKO (Aku Pintar Ekonomi) adalah produk pengembangan media berbasis aplikasi android dari Microsoft PowerPoint, pada mata pelajaran ekonomi materi pertumbuhan dan pembangunan ekonomi, untuk siswa kelas XI IPS 3 SMA Negeri 4 Malang. Pengembangan media pembelajaran ini disesuaikan dengan latar belakang berupa kebutuhan siswa dalam proses pembelajaran. Berdasarkan hasil validasi yang dilakukan peneliti bersama validator, diperoleh hasil validasi materi sebesar 100\% dengan keterangan sangat valid. Hasil validasi media diperoleh sebesar 92,307\% dengan keterangan sangat valid. Hasil validasi dari praktisi pembelajaran mendapatkan hasil sebesar $100 \%$ dengan keterangan sangat valid sehingga kesimpulan dari hasil validasi produk sangat layak untuk digunakan sebagai media pembelajaran.

\section{Daftar Rujukan}

Alam S. \& Rudianto. (2017). Ekonomi untuk SMA Kelas XI K13N. Jakarta: Erlangga.

Arikunto, S. (2008). Prosedur Penelitian Suatu Pendekatan Praktek. Jakarta: Rineka Cipta.

Eisa Inggrita Ellese. (2016). Ayo Belajar Cerdas: Ekonomi untuk SMA/MA Kelas XI Semester 1. Karanganyar: PT. Pratama Mitra Aksara

Indonesia, P. R. (2003). Undang-Undang Republik Indonesia Nomor 20 Tahun 2003 Tentang Sistem Pendidikan Nasional.

Mudlofir, Ali \& Rusydiah, E.F. (2007). Desain Pembelajaran Inovatif dari Teori ke Praktik. Jakarta. PT. Raja Grafindo Persada.

Mulyatiningsih, Endang. (2012). Metode Penelitian Terapan Bidang Pendidikan. Bandung. CV Alfabeta.

Nomor, P. (24). Tahun 2006 tentang Pelaksanaan Peraturan Menteri Pendidikan Nasional Nomor 22 Tahun 2006 tentang Standar Isi untuk Satuan Pendidikan Dasar dan Menengah Provinsi Jawa Barat

Nurjannah, R. I. (2019). Pengembangan Media Pembelajaran Pafrid Berbasis Aplikasi Android pada Mata Pelajaran Ekonomi Materi Perpajakan Kelas XI IPS 2 SMA Negeri 1 Grati Kabupaten Pasuruan. Skripsi tidak diterbitkan. Malang: FEB UM

Pamungkas, H. P. (2017). Pengembangan Pembelajaran Ekonomi Konstruktivistik. Tesis tidak diterbitkan. Malang: Pascasarjana Universitas Negeri Malang

Sugiyono. (2009). Metode Penelitian Pendidikan: Pendekatan Kuantitatif, Kualitatif, dan R\&D. Bandung. CV Alfabeta

Sugiyono, (2011). Statistika untuk Penelitian. Bandung: CV Alfabeta.

Sukmadinata, Nana S. (2012). Metode Penelitian Pendidikan. Bandung. PT. Remaja Rosdakarya.

Suparti. (2016). Metode Penelitian Pengembangan, Inovasi Pembelajaran, Beserta Contoh Proposal. Malang. UM Press

Setyosari, Punaji. (2007). Metode Penelitian Pendidikan. Malang. UM Press

Pendidikan, M. (2016). Peraturan Menteri Pendidikan dan Kebudayaan Republik Indonesia Nomor 21 Tahun 2016 tentang Standar Isi Pendidikan Dasar dan Menengah. Jakarta: Menteri Pendidikan dan Kebudayaan Republik Indonesia.

Pendidikan, P. M., \& Nomor, K. R. I. (64). Tahun 2013 tentang Standar Isi Pendidikan Dasar dan Menengah. Jakarta: Kementerian Pendidikan dan Kebudayaan. 